\title{
Analysis of Land-Use and Land-Cover Changes in YongDeng County Using Remote Sensing and GIS
}

\author{
Samuel Adingo ${ }^{1}$ Xiaodan $\mathrm{Li}^{2} \mathrm{Xue}-\mathrm{Lu} \mathrm{Liu}^{3 *} \mathrm{Jie}-\mathrm{Ru} \mathrm{Yu}^{3}$ \\ 1. College of Forestry, Gansu Agricultural University, Lanzhou, Gansu 730070, China. \\ 2. School of Management, Gansu Agricultural University, Lanzhou Gansu 730070, China. \\ 3. College of Resources and Environmental Sciences, Gansu Agricultural University, Lanzhou Gansu \\ 730070 , China. \\ * E-mail of the corresponding author: $\underline{\text { liuxl@gsau.cn }}$
}

The research is supported by the fundamental Research Funds of Gansu Provincial Natural Science Fund of "Research on Land Use and Ecological Security in Ecologically Vulnerable Areas" (Project No. GSAN-ZL-2015045) and Research on the Coordination Relationship between Land Urbanization and Population Urbanization (Project No. GSAU-ZL-2015-046).

\begin{abstract}
To generate reliable data on the spatiotemporal changes in land use and land cover in YongDeng county over a period of 24 years (1993 -2017) that will provide a basis for land use management decisions and policy formulation, this study used RS and GIS to analyze Landsat images of 1993, 2001, 2009 and 2017 of the study area which were acquired from the Geospatial Data Cloud (Http/westdc.westgis.ac.cn). Using supervised classification based on maximum likelihood classification method in ArcGIS (version 10.3) to classify images of the various years, the computed land use and land cover classes indicate that over the period of 24 years, significant Land use and land cover changes have occurred in the study area and the dominant land-use types in the study area were found to be grassland, bare land woodland and cultivated land occupying 65 percent, 20 percent, 8 percent and 6 percent of the study area respectively. As the years pass by, urban sprawl, population growth, agricultural activities, and other socio-economic activities in the study area, have led to rapid land-use transfer and change intensity. The results revealed that about $4.5 \mathrm{~km}^{2}$ of grassland, $3.21 \mathrm{~km}^{2}$ of bare land, $2.51 \mathrm{~km}^{2}$ of cultivated lands and $1.7 \mathrm{~km}^{2}$ of woodland were changed to construction lands from 1993-2017, whiles Cultivated lands, on the other hand, made gains of $2.56 \mathrm{~km}^{2}$ from Garden lands, $2.3 \mathrm{~km}^{2}$ from bare land and $1.05 \mathrm{~km}^{2}$ from woodland from 1993 to 2017. Whiles transport land, from 1993 to 2017 gained $3.3 \mathrm{~km}^{2}$ from bare land, $2.42 \mathrm{~km}^{2}$ from grassland, and $1.32 \mathrm{~km}^{2}$ from cultivated. Cultivated land, transportation land, construction land and water area and conservation land showed significantly positive land-use change intensity index of $2.19 \%, 1.97 \%, 1.49 \%$ and $1.31 \%$ respectively. Garden Land and woodland, though not significant also showed positive land-use change intensity of $0.55 \%$ and $0.79 \%$ respectively. The study identified population growth, urbanization and policy orientation as the main drivers of land use/land cover change in the area. The results reveal there is an urgent need to put measures in place to reduce the overexploitation of land in order to protect the integrity of biodiversity and to also ensure a continuous supply of valuable ecosystem services.
\end{abstract}

Keywords: Land-use/land-cover change, remote sensing, geographical information system, dynamic change, YongDeng County.

DOI: $10.7176 / \mathrm{JEES} / 10-6-15$

Publication date:June $30^{\text {th }} 2020$

\section{Introduction}

In a quest to provide resources for livelihood and to ensure food security for the ever-growing population of the world, humans for the past few centuries have been altering the earth's surface through various land use activities. These activities have led to serious environmental challenges such as land degradation and its associated detrimental effects which ultimately result in a change in land cover (Zhang, Liu and Henebry, 2019).

FAO/UNEP (1999), defines land use as the arrangements, activities, and inputs undertaken by people on a definite land cover type to provide change or maintain it. According to (Dami and Mayomi, 2016); (Vadrevu, Ohara and Justice, 2017), land use and land cover changes occur as a result of natural and socioeconomic influences. Increase in population, agricultural expansion, mining and clearing of land for development and urban sprawl among other anthropogenic activities are noted to be the drivers of change in the use of land and land cover (Vadrevu, Ohara and Justice, 2017).

The most prominent form of global environmental change that occurs at the spatiotemporal scale and affects our daily existence is land use and land cover change. Land use and land cover changes are the resulting effects of 
environmental forces acting on it and various anthropogenic activities carried out by man (Noszczyk, 2019). Aside from changing the spatial extent of land use and land cover classes, Land use and land cover changes also influence several other secondary processes such as soil erosion which eventually lead to loss of biodiversity and degradation of valuable ecosystems of the earth (Prabaharan et al., 2010); (Lázaro and Tur, 2018).

On this backdrop and to alleviate the detrimental environmental effects of land use and land cover change, and guarantee a more sustainable way of development, the Chinese Government launched various nationwide land restoration schemes and programs in the 1990s (Jia et al., 2014). These programs which included the Natural Forest Conservation Program (NFCP) and Grain for Green projects were aimed at preserving natural ecosystems, regenerating forests and reduce human pressure and dependence on fragile ecological regions (Wang et al., 2019). Despite these efforts by the government, land degradation and its associated damaging effects as a result of various land-use types continue unabated. The absence of reliable and appropriate land use and land cover change data can be pointed at as one of the major setbacks in properly addressing this environmental concern.

According to (Prabaharan et al., 2010); (Haladová and Petrovič, 2015), LULCC along with GIS and Remote Sensing data are employed in studies to detect changes that have occurred in a particular area over the years. The same method has been used by several other researchers such as (Santillan, Makinano and Paringit, 2010); (Haladová and Petrovič, 2015); (Khan et al., 2016); (Dami and Mayomi, 2016); (Abu Ghurah et al., 2018) and (Rahman, 2019), to quantify the extent of land use and land cover changes. Following this, the huge role of remote sensing and GIS in advancing research in land-use and land-cover change analysis cannot be downplayed.

YongDeng County located in the Gansu Province of China is an important ecological zone. It was declared as a national "Safe Agricultural Machinery" demonstration county in 2018 following the success it choked in agricultural activities. But Over the years, factors such as increased population and rapid urban expansion coupled with increased economic activities taking place have resulted in land use intensification. This study, therefore, seeks to use remote sensing and GIS to analyze the Spatio-temporal changes in land use and land cover in this area in order to produce precise and appropriate information that can be relied on to make land-use decisions and policy formulation and to also enhance proper ecosystem monitoring in land management.

\subsection{Materials and Methods}

\subsection{Study area}

The study area is found at Longitude $102^{\circ} 36^{\prime}$ to $103^{\circ} 45^{\prime} \mathrm{E}$ and Latitude $36^{\circ} 12^{\prime}$ to $37^{\circ} 07^{\prime} \mathrm{N}$. Stretching a distance of $107 \mathrm{~km}$ from north to south and $101 \mathrm{~km}$ from east to west, the study area covers an area of $6090 \mathrm{~km}^{2}$. The topography of the area is naturally hilly with landforms that are characterized by a staggered distribution of stony mountains and loess hills. The mountains overlap each other and the hills are undulating with the Yellow River and Zhuanlang River running through the southern part and middle part of the County respectively. YongDeng County has a continental climate with annual average temperature, annual average cooling water and annual average sunshine of $5.9^{\circ} \mathrm{C}, 290 \mathrm{~mm}$, and 2,659 hours respectively and a frost-free period of 121 days.

According to the 2010 population census, YongDeng County has 13 towns and the total population at the end of the year was 522,000 with a natural growth rate of 7.41\%. In terms of natural resources, YongDeng County has metal deposits including copper, aluminium, zinc, iron, manganese, and gold. As at 2010, the proven non-metallic mineral deposits included limestone reserves of approximately 294 million tons, quartzite reserves of approximately 310 million tons, gypsum reserves of 16.74 million tons, coal reserves of approximately 130 million tons, and mineral deposits such as marble and thenardite. Most of the inhabitants in this area are into agricultural activities and cultivate crops such as beans, vegetables, melons, peaches and many other cash crops. 


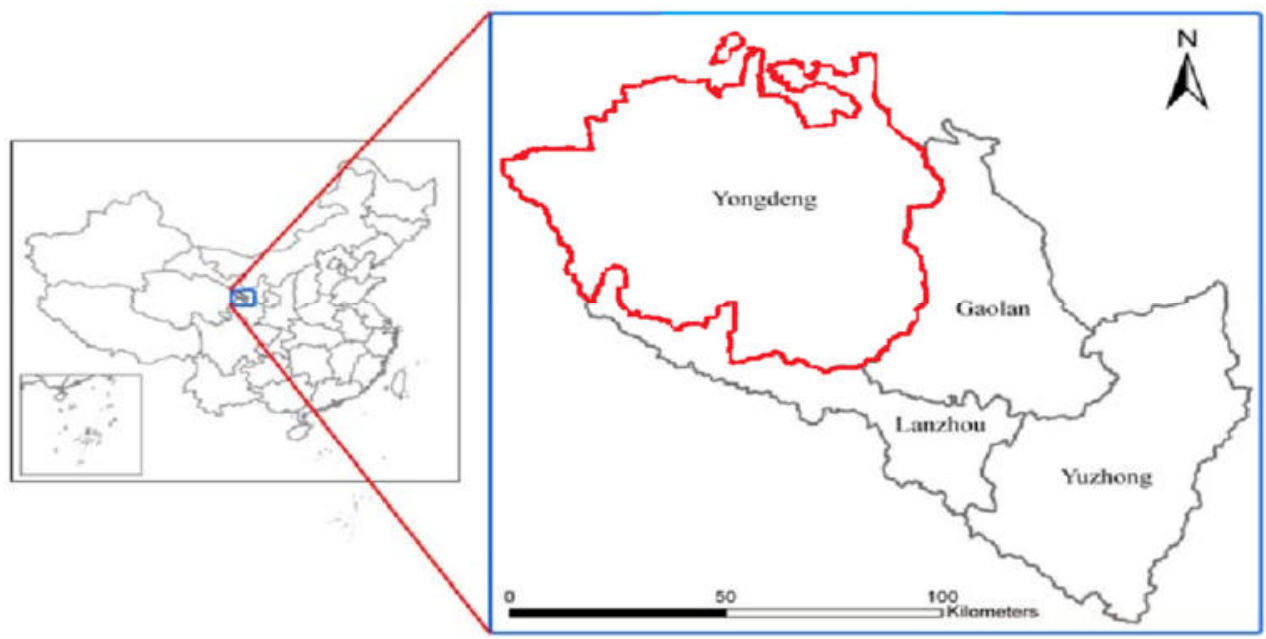

\subsection{Methodology}

Figure 2.1 Map of the study area

Prior to the start of this study, a two-day transect walk was carried out in the study area. This was done in order to interact with farmers and stakeholders in land use and land management issues and to also explore the area to get a deeper understanding of the area in terms of land use types and land management systems put in place.

\subsection{Satellite data acquisition}

The source of data for this study was Landsat remote sensing images of 1993, 2001, 2009, and 2017 of the study area which was acquired from the Geospatial Data Cloud (Http/westdc.westgis.ac.cn). The images covered path 134 and row of 061 . The images were acquired in the same season to reduce the influence of seasonal variation on land use and land cover analysis and were corrected geometrically to the Universal Transverse Mercator coordinate system.

\subsection{Image pre-processing}

Image processing was done using ArcGIS (version 10.3). The nearest neighbor method was used to resample images into $30 \times 30 \mathrm{~m}$ pixel size. Correction of Atmospheric variation was not done in this study. This was due to the fact that the adopted post-classification comparison (PCC) method compensated the variation in conditions of the atmosphere and phenology of vegetation for different dates (Ehlers et al., 2014); (Anjos et al., 2015). Supervised classification based on maximum likelihood classification method which is the most common method of supervised classification was used to classify images of each year independently.

\subsubsection{Accuracy assessment}

Assessment of accuracy in classification schemes is usually carried out to determine the quality of remotely sensed data/information generated after processing it. It is of utmost consistency when used together with ground position data or data from aerial photos at or close to the period of satellite overpass (Foody, 2010). To decrease the bias effect, the stratified random sampling design was employed where the sum of points was stratified to the types of land use and land cover change. The overall accuracy and K-statistic values were calculated using the formula below;

$$
\begin{aligned}
& \text { Overall Accuracy }(\mathrm{OA})=\frac{\sum_{i=1}^{K} n_{i i}}{n} \\
& \mathrm{~K}(\text { Kappa indices })=\frac{n \sum_{i=1}^{K} n_{i i}-\sum_{i=1}^{K} n_{i+} n_{+i}}{n^{2}-\sum_{i=1}^{K} n_{i+} n_{+i}}
\end{aligned}
$$

Where $\mathrm{n}=$ sum of observations made; $\mathrm{k}$ is the number of rows in the matrix; $n_{i i}$ is the number of observations in row $i$ and column $i ; n_{i+}$ is the sum of pixels in $i$ th row and $n_{+i}$ is the sum of the $i$ th row and $i$ th column.

\subsection{Change detection}

The Post-classification comparison (PCC) method was used to determine the LULC changes that have taken place 
from 1993-2017. PCC is a quantitative method that requires an independent classification of individual images from different dates for the same geographic location, followed by a comparison of the corresponding thematic labels in order to identify and quantify areas of changes (Burger and Burge, 2013); (Fonji and Taff, 2014). To obtain the area transfer matrix and change intensity of each land-use class in the area, an analysis of the land use data was done. The changing intensity of a single land use type was calculated using the formula;

$$
\mathrm{R}={ }_{U_{a}}^{U_{b}-U_{a}} \times \frac{1}{T} 100 \%
$$

Where $U_{a}$ and $U_{b}$ are the number of certain land-use types at the beginning and end of the study period respectively; $\mathrm{T}$ is the length of the study period and $\mathrm{R}$ is set as a year, which is the annual rate of a certain landuse type in the study period.

\subsection{RESULTS AND DISCUSSION}

\subsection{Conditions and land use types identified in the study area}

From the two-day field transect walk carried out, it was discovered that the study area is confronted with huge environmental challenges such as soil erosion. This was evidenced in gullies and channels formed as a result of water washing away soil from farmlands especially farms lands that are located uphill. Interactions with farmers revealed that the problem of soil erosion has persisted for some time despite their efforts in controlling it and this has resulted in low agricultural output.

\section{Table 4.1 LULC classes in the study area}

Land-use/land-cover class Description

Cultivated land

Garden land

Woodland

Grassland

Construction land

Transportation land

Water Area and Conservation land

Bare land
This includes all agricultural lands.

This land is used for growing ornamental plants, trees for aesthetic purposes.

Land covered by forest which may be dense or scattered.

Land covered with grass. It is often used for grazing by animals.

This type of land is made up of a permanent concentration of built-up structures such as houses, schools, etc.

The land occupied by roads, railways and transport systems.

This includes water bodies such as ponds, rivers, water reservoirs, and wetlands.

Areas with little or without vegetation.

\subsection{LULC Classification accuracy assessment}

The minimum level of accuracy that is satisfactory for a classification scheme according to (Anderson et al., 1976) is $85 \%$. In this study, the classification accuracy levels for the four different dates considered for this study were between $89.38 \%$ and $91.25 \%$ with an average of $89.17 \%$ whiles the Kappa indices of agreement were between 0.8699 and 0.8735 with an average of 0.8517 . The percentage range of accuracy for the classification and image processing of the various years was very effective as it is in consistent with the minimum acceptable level of accuracy that is required and hence produced very good compatible LULC data and images respectively.

\subsection{Land cover detection analysis using produced LULC maps}

Land-use change characteristics mainly refer to land area changes in spatial distribution and changes in land quality. The general situation of land use and changes in land use structure can be determined by land-use type to reflect the change in the area. According to the land use maps obtained in different periods, and from Table 4.2 below, it 
was found that grass land, bare land, woodland, and cultivated land were the dominant types of LULC classes for all the years under study. Computed percentages of LULC classes showed that in the year 1993, grassland, bare land woodland and cultivated land, occupied 65 percent, 20 percent, 8 percent and 6 percent of the study area, respectively, whereas construction land, transportation land, water area and garden land occupied only 6 percent.
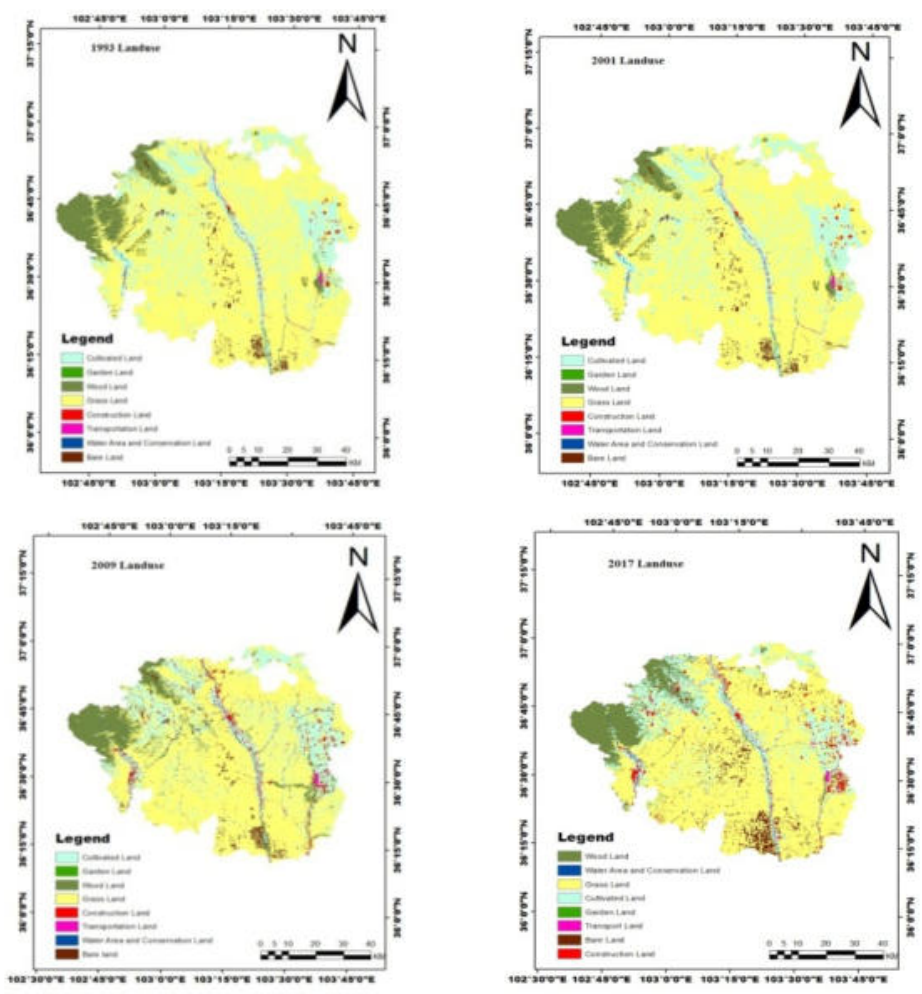

\subsection{Analysis of LULCC}

Table 4.2 LULCC (1993-2017)

\begin{tabular}{|c|c|c|c|c|c|c|c|c|c|c|c|c|c|c|c|c|}
\hline \multirow{2}{*}{ Landuse/Landcover classes } & \multicolumn{2}{|l|}{1993} & \multicolumn{2}{|l|}{2001} & \multicolumn{2}{|l|}{2009} & \multicolumn{2}{|l|}{2017} & \multicolumn{2}{|c|}{ Change(1993-2001) } & \multicolumn{2}{|c|}{ Change(2001-2009) } & \multicolumn{2}{|c|}{ Change(2009-2017) } & \multicolumn{2}{|c|}{ Overall change (1993-2017) } \\
\hline & $\operatorname{Area}(\mathrm{km})^{2}$ & $\%$ & Area $(\mathrm{km})^{2}$ & $\%$ & $\operatorname{Area}(\mathrm{km})^{2}$ & $\%$ & $\operatorname{Area}(\mathrm{km})^{2}$ & $\%$ & Area( $\left(\mathrm{Km}^{2}\right)$ & $\%$ & Area $\left(\mathrm{Km}^{2}\right)$ & $\%$ & Area $\left(\mathrm{Km}^{2}\right)$ & $\%$ & Area $\left(\mathrm{Km}^{2}\right)$ & $\%$ \\
\hline Cultivated land & 334.76 & 6 & 468.28 & 8 & 980.39 & 16.8 & 1008.5 & 17.3 & -468.28 & 40.0 & 16.8 & 110.0 & 991.7 & 59.0 & 540.22 & 100.0 \\
\hline Garden Land & 12.48 & 0 & 17.58 & 0.3 & 21.43 & 0.4 & 19.92 & 0.3 & -17.58 & 40.0 & 0.4 & 20.0 & 19.52 & -10.0 & 2.34 & -40.0 \\
\hline Wood land & 455.2 & 8 & 442.63 & 8 & 667.52 & 11.4 & 596.64 & 10.2 & -442.63 & -1.0 & 11.4 & 50.0 & 585.24 & -10.0 & 154.01 & 70.0 \\
\hline Grass land & 3821.2 & 65 & 3803.01 & 65 & 3769.28 & 64.5 & 3787.82 & 64.8 & -3803.01 & -1.0 & 64.5 & 13.0 & 3723.32 & 57.7 & -15.19 & -100.0 \\
\hline Construction Land & 25.44 & 0 & 105.4 & 2 & 184.71 & 3.2 & 192.59 & 3.3 & -105.4 & 310.0 & 3.2 & 80.0 & 189.39 & 59.2 & 87.19 & 560.0 \\
\hline Transportation Land & 12.17 & 0 & 14.94 & 0.3 & 29.92 & 0.5 & 34.77 & 0.6 & -14.94 & 20.0 & 0.5 & 100.0 & 34.27 & 20.0 & 19.83 & 90.0 \\
\hline Water Area and Conservation L & 13.98 & 0 & 25.27 & 0.4 & 28.09 & 0.5 & 19.02 & 0.3 & -25.27 & 80.0 & 0.5 & 10.0 & 18.52 & -30.0 & -6.25 & -60.0 \\
\hline Bare Land & 1169.3 & 20 & 967.42 & 16 & 163.19 & 3 & 185.27 & 3.2 & -967.42 & -20.0 & 3 & -80.0 & 182.27 & 10.0 & -782.15 & 180.0 \\
\hline
\end{tabular}

\subsubsection{Woodland coverage from 1993 to 2017}

From Table 4.2 above, woodland showed a dynamic trend from 1993 to 2017. In the year 1993, it covered about $8 \%\left(455.2 \mathrm{~km}^{2}\right)$ of the study area. It decreased to $7.8 \%\left(442.63 \mathrm{~km}^{2}\right)$ in 2001 and increased to $11.4 \%\left(667.42 \mathrm{~km}^{2}\right)$ and finally reduced slightly to $10.2 \%\left(596.64 \mathrm{~km}^{2}\right)$. Between 1993 and 2017 about $40 \%$ of woodland was lost. The area under woodland had reduced from the year 1993 to 2017 and that loss in the woodland area was compensated by gains in other land use types in the area. Increased agricultural activities and deforestation are the possible causes of a decline in the wood area. An increase in economic activities and population growth led to more woodland converted to construction land and cultivation land respectively for food production. 


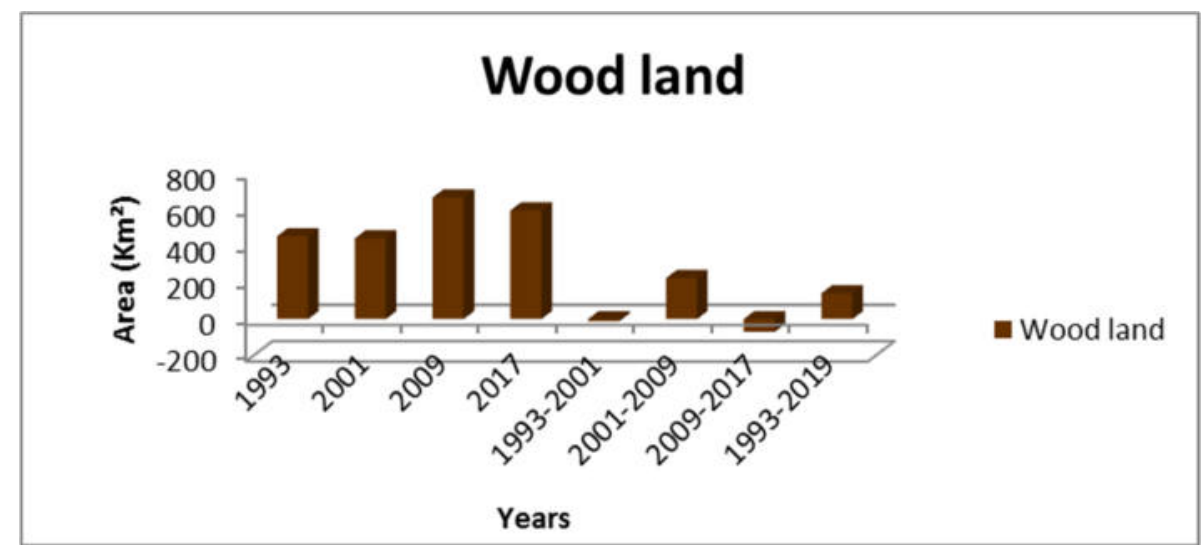

Fig. 4.1 woodland (1993-2017)

\subsubsection{Cultivated land coverage from 1993 to 2017}

Farmers in the study area consider cultivation a better livelihood strategy due to available markets from increasing populations. From occupying approximately $6 \%\left(334.76 \mathrm{~km}^{2}\right)$ of the study area in 1993 , cultivated lands increased to $8 \%\left(468.28 \mathrm{~km}^{2}\right)$ and $16.8 \%\left(980.39 \mathrm{~km}^{2}\right)$ in 2001 and 2009 respectively and finally increased to $17.3 \%$ $\left(1008.5 \mathrm{~km}^{2}\right)$ in 2017 . From 1993 to 2017 area of land under cultivation has increased by approximately $100 \%$. Population growth could be pointed at as the cause for the expansion in cultivated land in the area. (Meneses $e t$ al., 2017) and (Hoyos, Cabido and Cingolani, 2018) reported in their studies that changes in land-use and land cover are brought about when natural vegetation or previously forested areas are converted to other land use types such as cultivated land, construction land, etc. as the population grows.

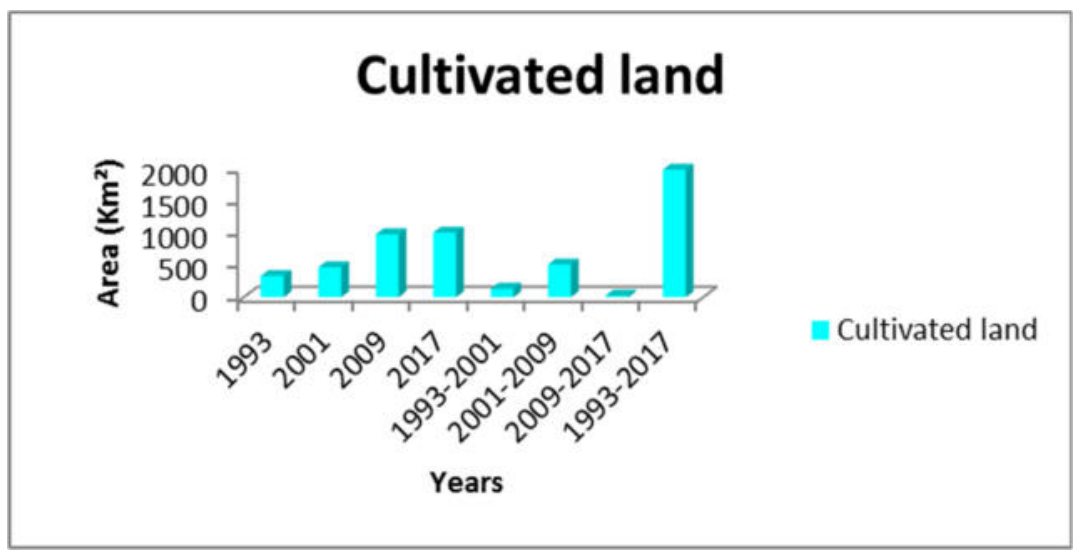

Fig 4.2 Cultivated lands (1993-2017)

\subsubsection{Grassland coverage from 1993 to 2017}

From the results, there was no significant change in grassland coverage from 1993 to 2017. From occupying $65 \%$ $\left(3821.2 \mathrm{~km}^{2}\right)$ of the study area in 1993 , grassland slightly reduced in 2001 . It further reduced to $64.5 \%\left(3769.28 \mathrm{~km}^{2}\right)$ in 2009 but increased slightly to $64.8 \%\left(3787.82 \mathrm{~km}^{2}\right)$ in 2017 . In the study area, a large proportion of the grassland is located on hills and mountains. The location of these lands on hills and mountains makes their accessibility and usage virtually impossible hence their usage for grazing animals. Notwithstanding this, there has been a concerted effort by the government and relevant stakeholders to turn these grassland areas into forest areas. 


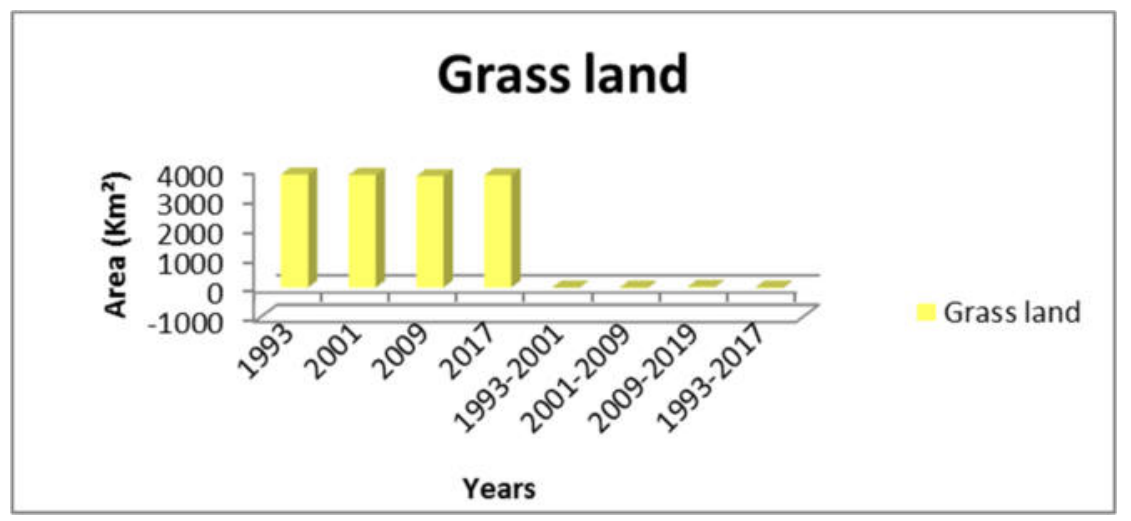

Fig 4.3 Grassland (1993-2017)

4.5.4 Bare land coverage from 1993-2017

Bare land just like the other land-use types has significantly changed during the period of study (1993-2017). It covered about $20 \%\left(1169.3 \mathrm{~km}^{2}\right)$ in 1993 . In the year 2001 , is reduced to $16 \%\left(967.42 \mathrm{~km}^{2}\right)$ and a further reduction to $3 \%\left(163.19 \mathrm{~km}^{2}\right)$ in the year 2009 . It finally increased to $3.2 \%\left(185.27 \mathrm{~km}^{2}\right)$ by 2017 . The initial high land cover area of bare land was due to the removal of natural vegetation, intensive cultivation on these fragile lands, and overgrazing without effective conservation measures. Also, farmers in the study area abandon degraded lands for new ones when they are no longer productive. These areas of land abandoned by farmers due to their unsuitability for grazing and farming are exposed to severe environmental conditions such as soil erosion. But as the years pass by, bare land areas were converted into other land-use types such as construction and transportation resulting in a reduction in bare lands in the study area.

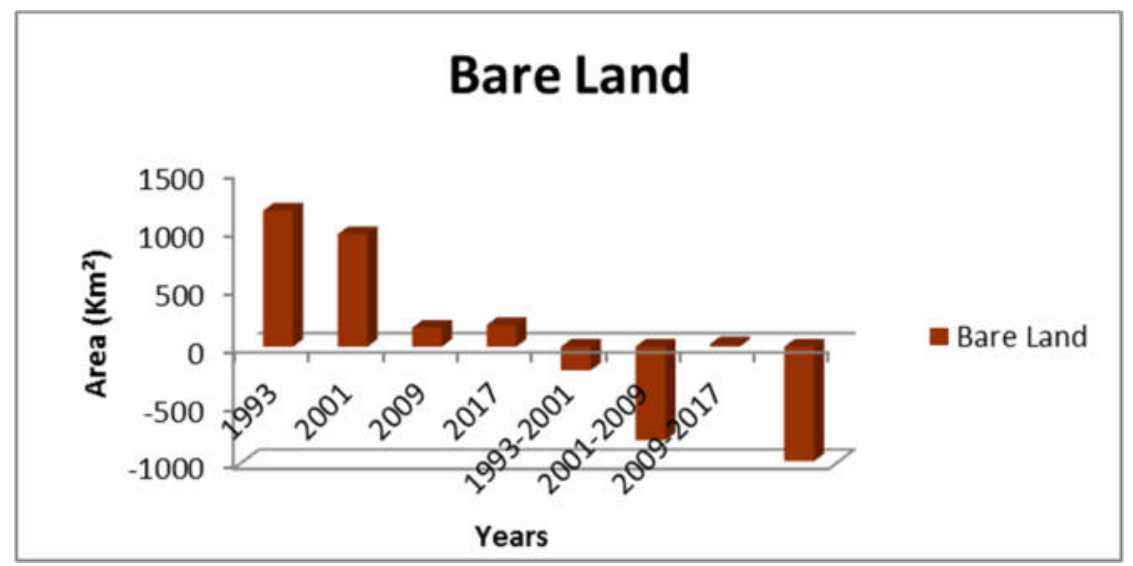

Fig. 4.4 bare land (1993-2017)

\subsubsection{Water area and conservation land coverage from 1993 to 2017}

In the study area, the Yellow and Zhuanlang rivers flow through the southern part and middle part respectively, serving as a source of water for irrigation farming and other hydrological services. To ensure an all year-round farming in order to guarantee a continuous supply of agricultural produce, Reservoirs, and channels of water have been created from these rivers to flow through adjacent lands for irrigation farming. As a result, the area of land underwater and conservation has increased since 1993. Following a large-scale national ecological security, much attention has been given to conserving lands in order to protect biodiversity and ensure a continuous supply of valuable ecosystem services. This has resulted in an increase in conservation lands in the study area. Table 4.2 shows that water area and conservation lands occupied $0.2 \%\left(13.98 \mathrm{~km}^{2}\right)$ of the area in the year 1993 . However, it increased to $0.4 \%\left(25.27 \mathrm{~km}^{2}\right)$ and $0.5 \%\left(28.09 \mathrm{~km}^{2}\right)$ in the years 2001 and 2009 respectively and finally increased to $0.3 \%\left(19.02 \mathrm{~km}^{2}\right)$ in 2017 . The increasing trend of water area and conservation land is consistent with an increase in agricultural activities which demanded the construction of dams and water channels for irrigation farming. 


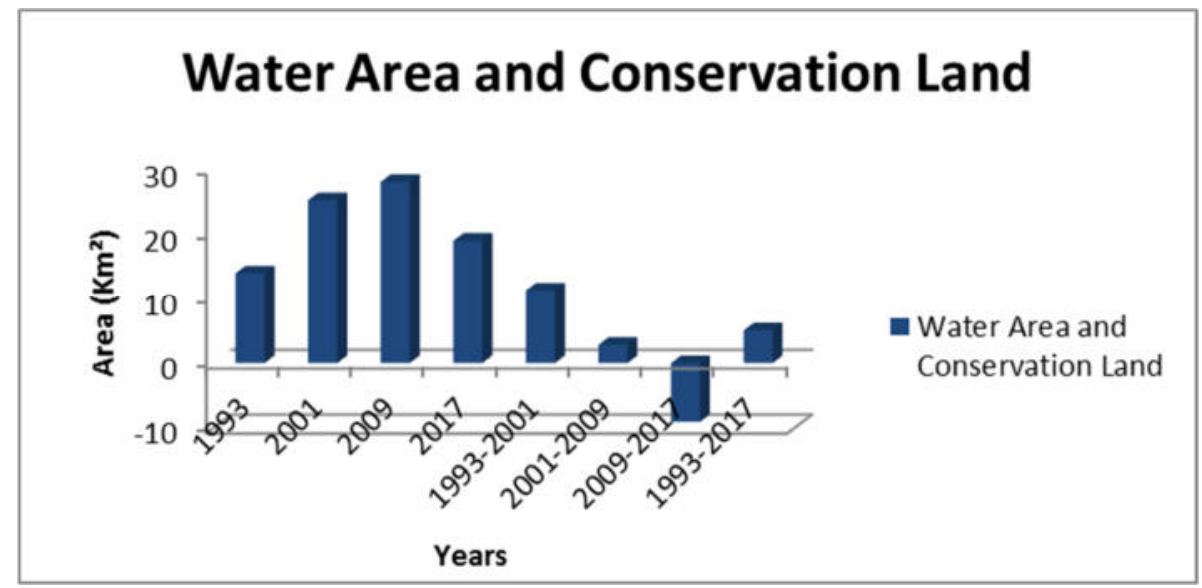

Fig. 4.5 water and conservation land (1993-2017)

4.5.6 Construction land coverage from 1993-2017.

Population growth coupled with other socio-economic factors occurs with a corresponding demand for housing, roads, and social amenities which cannot be provided without making use of land space. In the study area, the cover of land under construction increased significantly from 1993 to 2017. From Table 4.2, construction land occupied about $0.4 \%(25.44 \mathrm{~km})$ whiles in 2001 and 2009 it increased by $2 \%(105.4 \mathrm{~km})$ and $3.2 \%(184.71 \mathrm{~km})$ respectively and finally increased to $3.2 \%$ to cover $184.71 \mathrm{~km}$ of the area in 2017 .

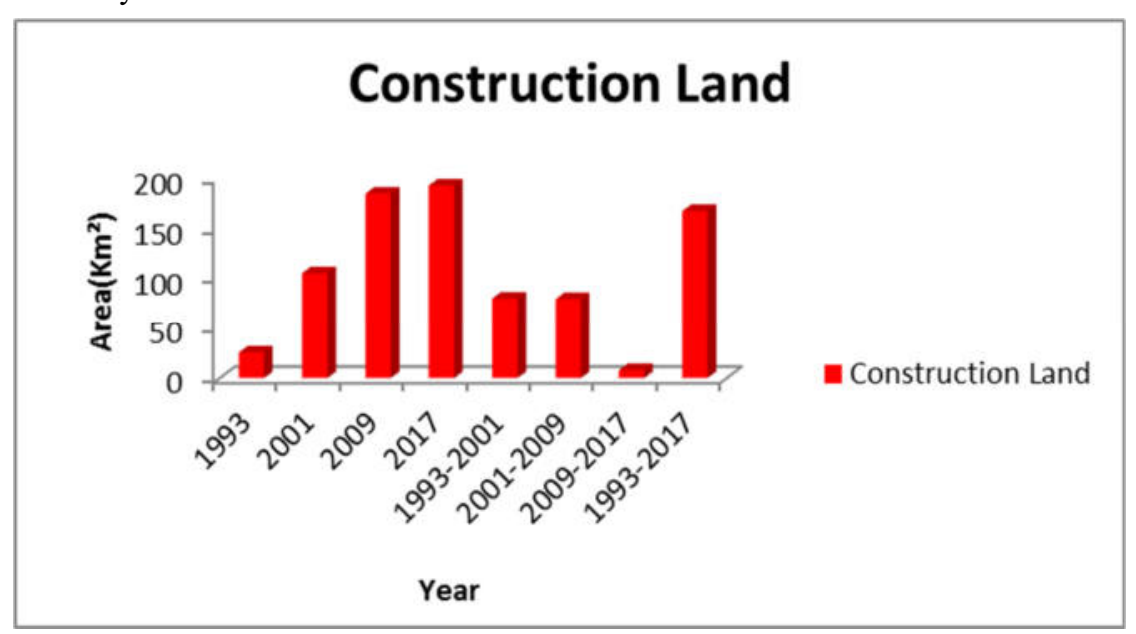

Fig. 4.6 construction land (1993 - 2017)

4.5.7 Transportation land coverage from 1993 to 2017

The requisition of the construction of highways, railways, and other transportation projects reflect the economic development of the study area. Per the results in Table 4.2, there has been an upsurge in the area of land occupied by transportation. In 1993, it covered $0.2 \%\left(12.17 \mathrm{~km}^{2}\right)$ of the study area and increased to $0.3 \%\left(14.94 \mathrm{~km}^{2}\right)$ in 2001. As the study area continues to expand in terms of urbanization, the need for the good road network to link very important areas and to enhance the easy conveying of agricultural goods from farms, led to a further increase in transportation lands from $0.5 \%\left(29.92 \mathrm{~km}^{2}\right)$ in 2009 to $0.6 \%\left(34.77 \mathrm{~km}^{2}\right)$ in 2017. 


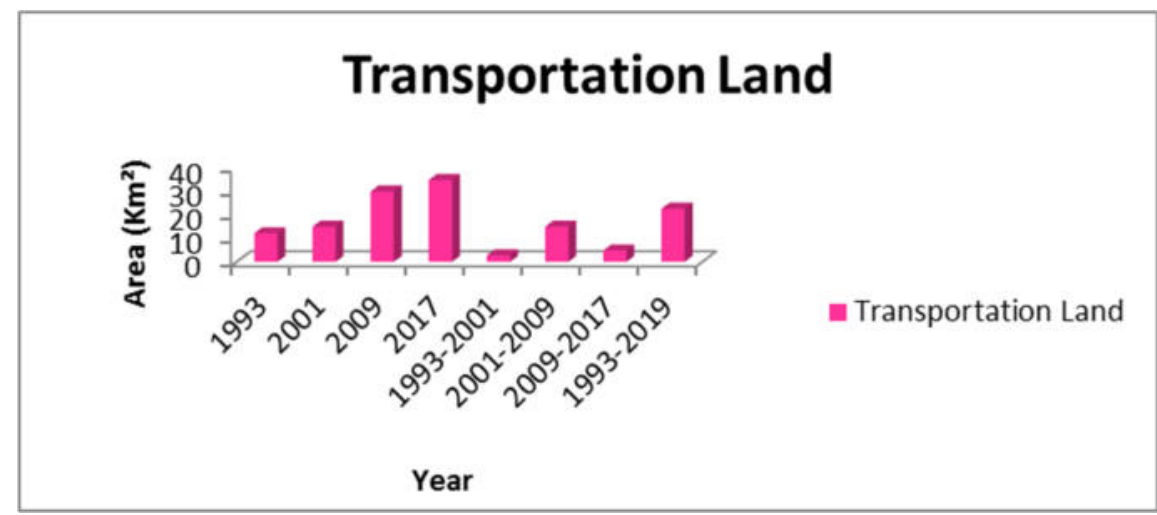

Fig. 4.7 transportation land (1993-2017)

4.5.8 Garden land coverage from 1993 to 2017

From serving aesthetic purposes to providing important ecological services, garden lands play significant roles in preserving the biodiversity and integrity of the ecosystem of an area. In the study area and making reference to the results in Table 4.2, the area of land under the garden has seen significant changes. It covered $0.2 \%\left(12.48 \mathrm{~km}^{2}\right) \mathrm{of}^{2}$ the area in 1993 and increased to $0.3 \%\left(17.58 \mathrm{~km}^{2}\right)$ in 2001 . However, it reduced from $0.4 \%\left(21.43 \mathrm{~km}^{2}\right)$ in 2009 to $0.3 \%\left(19.92 \mathrm{~km}^{2}\right)$ in 2017. The increase in garden lands from 1993 to 2009 was influenced by the Chinese government's policies and programs such as green for grain projects and the Natural Forestation Program (NFP) which were aimed at preserving the natural ecological environment.

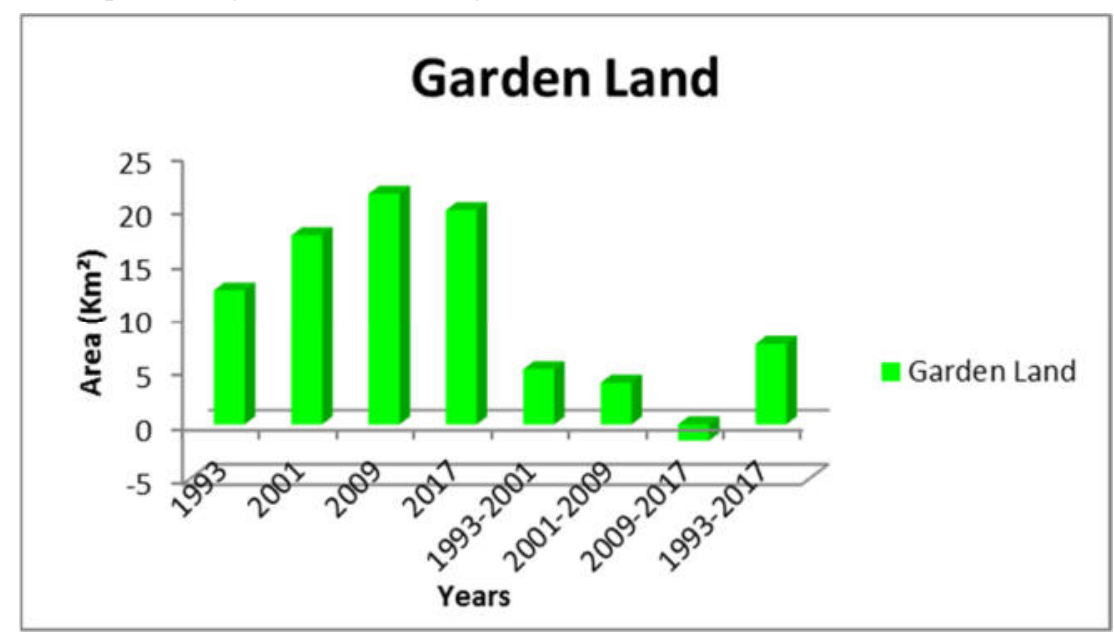

Fig. 4.8 garden land (1993-2017)

\subsection{Land use transfer matrix and change intensity}

With reference to the spatial distribution and the characteristics of how land is used in the study area, significant changes have occurred under the period of study (1993-2017). Table 4.3 below shows the land use transfer situation in YongDeng County which reveals that different land types have been changed into other land-use types. Construction land, cultivated land, and transportation land made significant gains from other land-use types such as bare land, grassland, and woodland. Approximately $4.5 \mathrm{~km}^{2}$ of grassland, $3.21 \mathrm{~km}^{2}$ of bare land, $2.51 \mathrm{~km}^{2}$ of cultivated lands, and $1.7 \mathrm{~km}^{2}$ of woodland were changed to construction lands from 1993-2017. Cultivated lands, on the other hand, made gains of $2.56 \mathrm{~km}^{2}$ from Garden lands, $2.3 \mathrm{~km}^{2}$ from bare land, and $1.05 \mathrm{~km}^{2}$ from woodland from 1993 to 2017. Whiles transport land, from 1993 to 2017 gained $3.3 \mathrm{~km}^{2}$ from bare land, $2.42 \mathrm{~km}^{2}$ from grassland and $1.32 \mathrm{~km}^{2}$ from cultivated. The transfer of the other land use types into construction lands, cultivated lands and transport lands is in consistent with the increase in population, agricultural and socioeconomic activities over the years in the study area. 
Table 4.3 land use transfer in the study area 2017

\begin{tabular}{|c|c|c|c|c|c|c|c|c|c|}
\hline \multicolumn{10}{|c|}{2017} \\
\hline & Landuse/ landcover class & \multicolumn{8}{|c|}{ Cult. Land Gard. Land Wood Land Grass Land Const. Land Transp. Land Water \& Co Bare Lanc } \\
\hline \multirow{8}{*}{1993} & Cultivated Land & 334.76 & 0.12 & 0.4 & 0.32 & 2.51 & 1.32 & 0.3 & 1.2 \\
\hline & Garden Land & 2.45 & 12.48 & 0.1 & 0.11 & 0.9 & 1.2 & 1.32 & 0.26 \\
\hline & Wood Land & 1.05 & 0.2 & 455.2 & 0.33 & 1.7 & 0.92 & 0.4 & 0.96 \\
\hline & Grass Land & 0.21 & 0.1 & 0 & 3821.2 & 4.51 & 2.42 & 1.2 & 0.55 \\
\hline & Construction Land & 0.01 & 0 & 0.3 & 0.01 & 25.44 & 1.85 & 0.65 & 1.21 \\
\hline & Transportation Land & 0.02 & 0 & 0 & 0 & 0 & 12.17 & 0 & 0.1 \\
\hline & Water \& and Cons. Land & 0.4 & 1.3 & 0.6 & 0.01 & 0.23 & 0.98 & 19.98 & 13.98 \\
\hline & Bare Land & 2.3 & 1.2 & 0.32 & 0.47 & 3.21 & 3.3 & 3.23 & 1169.3 \\
\hline
\end{tabular}

Under the period of years considered for this study (1993-2017), the rapid land-use change rate has taken place in the study area. From Table 4.3 below, land use types such as cultivated land, transportation land, Construction Land and water area, and conservation land showed significantly positive land-use change intensity index of $2.19 \%$, $1.97 \%, 1.49 \%$, and $1.31 \%$ respectively. Garden Land and woodland, though not significant also showed positive land-use change intensity of $0.55 \%$ and $0.79 \%$ respectively. Grassland area and bare land area, on the other hand, recorded negative values of -0.24 and -1.15 respectively indicating a decrease in these areas from 1993-2017.

Table 4.3 Land use change intensity in the study area (\%)

\begin{tabular}{lllll}
\hline Land use/Land cover classes & $\mathbf{1 9 9 3 - 2 0 0 1}$ & $\mathbf{2 0 0 1 - 2 0 0 9}$ & $\mathbf{2 0 0 9 - 2 0 1 7}$ & $\mathbf{1 9 9 3 - 2 0 1 7}$ \\
\hline Cultivated land & 0.29 & 2.38 & 3.92 & 2.19 \\
Garden Land & 0.21 & 0.53 & 0.9 & 0.55 \\
Wood land & 1.98 & -0.65 & 1.05 & 0.79 \\
Grass land & 3.4 & -1.81 & -2.3 & -0.24 \\
Construction Land & 0.87 & 1.23 & 2.37 & 1.49 \\
Transportation Land & 0.45 & 1.64 & 3.82 & 1.97 \\
Water Area and Cons. Land & 0.25 & 1.71 & 1.98 & 1.31 \\
Bare Land & 0.55 & -1.91 & -2.1 & -1.15 \\
\hline
\end{tabular}

(+value indicate increase LULC type/class, -value indicate decreased LULC type/class over the years)

\subsection{Driving forces of land-use change in the study area}

The driving forces of land use refer to all the different kinds of direct and indirect factors that lead to the change of land use mode and purpose which include both natural and socio-economic driving force (Li et al., 2016). Below are some of the drivers of land-use land-cover changes in the study area;

Population; According to data from Gansu Province statistical yearbook, the correlation coefficient between population and cultivated land change is -0.9321 , which is highly correlated with an increase of 522, 000 in the YongDeng County population from 1995-2010. As a result, the demand for housing, transportation, and public facilities has increased and the non-agricultural industries and towns have seen continuous trends of development resulting in the reduction of the number of bare lands and grasslands.

Urbanization; the influence of urbanization level on land-use change in the study area cannot be ignored. According to the 2010 population census, the county has a population growth rate of $7.41 \%$ per annum and the proportion of the urban and rural population was $1: 1.63$ and the level of urbanization as $38 \%$ which increased by 12 percentage points. With the increase in population, the demand for urban infrastructure and residential land increased and the change of lifestyle and values also aggravated the trend of non-agricultural land use.

Policy; the impact of policy orientation on land-use change in YongDeng County cannot be ignored. The green for grain project which was started in Shanxi in 1998 and other strategic land use plans proposed by the government have had a significant influence on land-use change in the study area. These projects have led to the conversion of certain land-use types to garden lands and conservation lands in order to restore and protect the integrity of 
biodiversity and ecological services in the area.

\subsection{Conclusion and recommendation}

YongDeng County in the Gansu Province of China plays an important role in the socio-economic development of the area through agricultural activities, mining, and other related economic activities. This is evidenced in the declaration of the county as national safe agricultural machinery in 2018. Despite this success, the area faces serious environmental challenges such as soil erosion from field observations.

1. The outcome of this study has revealed that significant changes in the spatial distribution of various LULC types/cover in the study area have taken place from 1993-2017.

2. With construction land, grassland and bare land being the dominant land classes in the area, rapid population growth coupled with an intensification of agricultural activities, government policies and other socio-economic factors have resulted in high land use transfer rates and increased land-use change intensity. Cultivated land, construction land and transportation land were the major land types that made significant gains from other land use types in the area under the period of study (1993-2017) whiles areas under grassland and bare land was lost to other land use types under the same period of study.

3. With the increasing trend in construction land, cultivated land and transportation lands witnessed from the results of the study in this area from 1993-2017, it is highly recommended that proper land use measures are put in place to control overexploitation of land in order to preserve the integrity of biodiversity and valuable ecosystem. A recommendation is made through this research for further studies to examine the effect of different land-use types on the value of the ecosystem.

\section{References}

Abu Ghurah, M. H. et al. (2018) 'Assessment of urban growth and sprawl using GIS and remote sensing techniques in South Ghor region, Al-Karak, Jordan', International Journal of Engineering and Technology(UAE), 7(3.14 Special Issue 14). doi: 10.14419/ijet.v7i3.14.16853.

Anderson, J. R. et al. (1976) 'LAND USE AND LAND COVER CLASSIFICATION SYSTEM FOR USE WITH REMOTE SENSOR DATA.', U S Geol Surv, Prof Pap, (964).

Anjos, D. et al. (2015) 'Change detection techniques using multisensor Data', in Remotely Sensed Data Characterization, Classification, and Accuracies. doi: 10.1201/b19294.

Burger, W. and Burge, M. (2013) Principles of Digital Image Processing: Advanced Methods, Principles of Digital Image Processing. doi: 10.1007/978-1-84882-919-0.

Dami, A. and Mayomi, I. (2016) 'A \{Geospatial\} \{Analysis $\}$ of land use and land cover change in $\{$ Hadejia $\}$ $\{$ Nguru $\}$ Wetlands\}, \{Yobe $\}$ State $\},\{$ Nigeria\}', Journal of Social and Management Sciences, 2(1).

Ehlers, M. et al. (2014) 'Automated techniques for change detection using combined edge segment texture analysis, GIS, and 3D information', in Global Urban Monitoring and Assessment: Through Earth Observation. doi: $10.1201 / \mathrm{b} 17012-22$.

Fonji, S. F. and Taff, G. N. (2014) 'Using satellite data to monitor land-use land-cover change in North-eastern Latvia’, SpringerPlus, 3(1). doi: 10.1186/2193-1801-3-61.

Foody, G. (2010) 'Assessing the Accuracy of Remotely Sensed Data: Principles and Practices', The Photogrammetric Record, 25(130). doi: 10.1111/j.1477-9730.2010.00574_2.x.

Haladová, I. and Petrovič, F. (2015) 'Classification of land use changes (Model Area: Nitra Town)', Ekologia Bratislava, 34(3). doi: 10.1515/eko-2015-0024. 
Hoyos, L. E., Cabido, M. R. and Cingolani, A. M. (2018) 'A multivariate approach to study drivers of land-cover changes through remote sensing in the dry Chaco of Argentina', ISPRS International Journal of Geo-Information, 7(5). doi: 10.3390/ijgi7050170.

Jia, X. et al. (2014) 'The tradeoff and synergy between ecosystem services in the Grain-for-Green areas in Northern Shaanxi, China', Ecological Indicators, 43. doi: 10.1016/j.ecolind.2014.02.028.

Khan, S. et al. (2016) 'Spatio-Temporal Analysis of Landuse/Landcover Change of District Pishin Using Satellite Imagery and GIS', Journal of Geographic Information System, 08(03). doi: 10.4236/jgis.2016.83031.

Lázaro, A. and Tur, C. (2018) 'Land-use changes as drivers of pollinator declines', Ecosistemas. doi: 10.7818/ECOS.1378.

Li, X. et al. (2016) 'Physical and socioeconomic driving forces of land-use and land-cover changes: A Case Study of Wuhan City, China', Discrete Dynamics in Nature and Society, 2016. doi: 10.1155/2016/8061069.

Meneses, B. M. et al. (2017) 'Understanding driving forces and implications associated with the land use and land cover changes in Portugal', Sustainability (Switzerland), 9(3). doi: 10.3390/su9030351.

Noszczyk, T. (2019) 'A review of approaches to land use changes modeling', Human and Ecological Risk Assessment. doi: 10.1080/10807039.2018.1468994.

Prabaharan, S. et al. (2010) 'Remote Sensing and GIS Applications on Change Detection Study in Coastal Zone Using Multi Temporal Satellite Data', International Journal of Geomatics and Geosciences, 1(2).

Rahman, M. N. (2019) 'Urban Expansion Analysis and Land Use Changes in Rangpur City Corporation Area, Bangladesh, using Remote Sensing (RS) and Geographic Information System (GIS) Techniques', Geosfera Indonesia, 4(3). doi: 10.19184/geosi.v4i3.13921.

Santillan, J., Makinano, M. and Paringit, E. (2010) 'Detection of 25-year land-cover change in a critical watershed in Southern Philippines using Landsat MSS and ETM+ images: importance in watershed rehabilitation.', International Archives of Photogrammetry, Remote Sensing and Spatial Information Sciences, 38(Part 7A, ISPRS TCVII Symposium - 100 Years ISPRS: Advancing Remote Sensing Science, Vienna, Austria).

Vadrevu, K., Ohara, T. and Justice, C. (2017) 'Land cover, land use changes and air pollution in Asia: A synthesis', Environmental Research Letters. doi: 10.1088/1748-9326/aa9c5d.

Wang, Y. et al. (2019) 'The Grain for Green Project intensifies evapotranspiration in the revegetation area of the Loess Plateau in China', Kexue Tongbao/Chinese Science Bulletin, 64(5-6). doi: 10.1360/N972018-00515.

Zhang, X., Liu, L. and Henebry, G. M. (2019) 'Impacts of land cover and land use change on long-term trend of land surface phenology: A case study in agricultural ecosystems', Environmental Research Letters, 14(4). doi: 10.1088/1748-9326/ab04d2. 